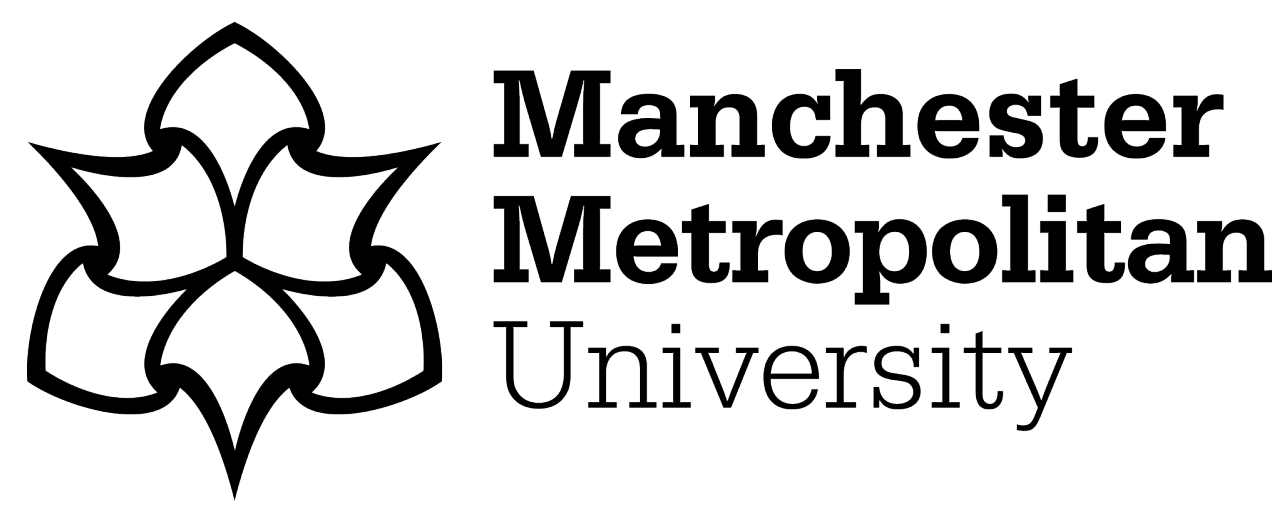

Rubery, J and Hebson, G ORCID logoORCID: https://orcid.org/0000-00030943-9848 (2018) Applying a gender lens to employment relations: Revitalisation, resistance and risks. Journal of Industrial Relations, 60 (3). pp. 414-436. ISSN 0022-1856

Downloaded from: https://e-space.mmu.ac.uk/628667/

Version: Accepted Version

Publisher: Sage

DOI: https://doi.org/10.1177/0022185618766680

Please cite the published version 


\title{
Applying a gender lens to employment relations: Revitalisation, resistance and risks
}

\author{
Jill Rubery (1) and Gail Hebson
}

University of Manchester, UK

\begin{abstract}
Employment relations is on the defensive. A gender lens provides opportunities for revitalisation through bringing in social reproduction alongside production, introducing intersectional identities alongside class, developing gendered critiques of 'neutral' markets and recognising the 'doing of gender' within the workplace. However, resistance within research and practice is evident in gender blindness, marginalisation of gender issues or preference for male interests. Three risks associated with a gender lens are identified: first, feminist critiques may be used by employers or neoliberal policymakers to deregulate employment; second, by making gender visible, gender differences may be used to legitimise gender inequalities; and third, in representing workers' interests many pitfalls need to be navigated in steering a path between excessive fragmentation and reproducing hierarchy, whether by class, gender or race. Nevertheless, the costs of not embracing a gender perspective go beyond missed opportunities for renewal and leave employment relations at risk of further decline.
\end{abstract}

\section{Keywords}

Body work, employment relations, gender, intersectionality, marketisation, social reproduction

\section{Introduction}

The public sphere of employment can no longer be considered a primarily male preserve. Now that women account for $44 \%$ of total Organisation for Economic Co-operation and Development (OECD) employment, even the most died-in-thewool traditionalists accept the consideration of gender issues within employment

\section{Corresponding author:}

Jill Rubery, Work and Equalities Institute, Alliance Manchester Business School, University of Manchester, Booth Street West, Manchester MI5 6PB, UK.

Email: jill.rubery@manchester.ac.uk 
relations (ER). Now ER texts commonly include chapters or sections on gender or diversity (see e.g. Colling and Terry, 2010; Dibben et al., 2011; Martinez Lucio, 2014; Wilkinson et al., 2014). This is not universal, but still contrasts with the almost complete absence of even references to gender 20 or 30 years ago (Rubery and Fagan, 1995; Wajcman, 2000). However, simply adding in women's issues is insufficient, as Judy Wajcman has (2000: 184). Drawing on these feminist critiques of the continued 'add on' approach to gender within ER (Ledwith, 2012a; Wacjman, 2000) and on feminist debates in sociology and management and organisation studies, we argue the need to apply what we label a gender lens to ER (see also Hebson and Rubery, 2018). This mainstreaming approach, as Pocock (1997: 13) argues, calls into question taken-for-granted knowledge and requires rethinking and reconceptualising core concepts and underlying principles. Applying a gender lens has thus the potential to renew and revitalise a subject area that has long been at risk of marginalisation on the grounds that it is outdated or dying (for review, see Lansbury, 2009; Piore, 2011).

Yet to date, these new challenges have, as we document in the following, induced often only muted responses or even active resistance. Questioning of key foundations and principles always comes with risks. These extend beyond the marginalising of either gender or class interests to the risk of providing succour to those wishing to marginalise the discipline and practice of ER. Risks increase in a context of overt hostility to collective approaches to work and the employment relationship. Gender research has gone further in disciplines such as management and organisational studies (Broadbridge and Simpson, 2011; Calás et al., 2014), but even here concerns have been raised that gender equality goals may be being subverted to the needs of capitalism (Calás et al., 2014: 38).

A gender lens, therefore, not only provides opportunities for revitalisation, but may also invoke resistance and risks. The article is organised as follows. The next section outlines four key ways through which a gender lens could revitalise ER as a subject area, and identifies the forms that resistance may take and the types of risks that may be encountered. This framework is then applied in turn to each of the four areas through a review of both research evidence and policy debates and actions. The conclusions consider the implications for the future of ER research and practice.

\section{Revitalisation, resistance and risks: The implications of a gender lens}

ER is a subject on the defensive. Traditionally focused on the institutions of trade unions and collective bargaining using a descriptive static systems approach (Dunlop, 1958), the subject area has been both widened and repositioned. This is indicated by its renaming from 'industrial' to 'employment' relations and by efforts to reconnect to social science strands from comparative politics and production systems (Crouch, 1993), through labour process debates to human resource management (see Ackers and Wilkinson, 2003, for a review of the interlinkages with social science). ER research on gender remains primarily the preserve of female ER 
scholars taking a feminist perspective, although a small number of male scholars have taken up the issues (see e.g. Berg and Piszczek, 2014; Fleetwood, 2007; Grimshaw and Rubery, 2007; Heery, 2003; Heery and Conley, 2007).

The contention is that a more mainstreamed gender lens, informed by gender scholarship in ER and associated disciplines, could provide a basis for revitalisation by addressing four key lacunae in ER's traditional frameworks (Hebson and Rubery, 2018). The first lacuna is ER's neglect of social reproduction, an issue at the heart of the feminist critique of ER for ignoring how unpaid work 'frees up' male labour for wage work and how the marginalisation of care work may in part explain the growth of precarious work. The second is its focus on class identities or interests to the neglect of more complex notions of identity and interests that have developed just as class identities have waned. A gender lens provides the stimulus to start to consider the intersections of a multiplicity of social divisions and differences and provides a framework for extending trade union organisation to excluded groups. A third deficiency in ER is the lack of a fully effective narrative to counter the increasing 'marketisation' of ER. A gender lens could provide a new means of challenging the apparent neutrality of markets and thereby help defend collective and political efforts to protect against exploitation. Finally ER has been concerned with the material and political aspects of people's work experience to the neglect of the physical, emotional and sexual aspects that make us fully human and not solely economic or political subjects. A gender lens provides a response to these limitations by embodying work and recognising that gender is not only brought into the workplace, but is also configured and reconfigured at work through the 'doing of gender'.

Thus a gender lens can provide new insights into core issues at the centre of the ER discipline and establish a revitalised, dynamic and extended research agenda, thereby helping to counter queries over its continuing salience. However, these opportunities have not been fully embraced by the ER profession, both academic and practitioner. In charting the missed opportunities, we look for evidence of resistance. This may take varying forms, including gender blindness, gender marginalisation and gender preference. Gender blindness implies a lack of engagement and an acceptance of a false gender neutrality embedded in both organisational practices (Acker, 2006) and collective agreements (Dickens, 2000). Gender marginalisation recognises gender issues but places them in a silo within ER, where female-specific issues related to their presumed greater care responsibilities can be addressed without challenging the prevailing organisation of work and working life. Marginalisation is easier and less disruptive than the mainstreaming approach advocated by Dickens (2000: 201), where

there is not necessarily an 'equality agenda' separate from the bargaining agenda. 'Core' negotiating issues such as working time, wage adjustment, flexibility, restructuring, etc., which do not come brandishing an equality label, are of central importance to the promotion of equality. An equality dimension to all such bargaining is needed in addition to bargaining over specific equality measures. 
Marginalisation is also evident in resistance to theorisation of men's position and experiences (Cockburn, 1985; Wajcman, 2000). Actors in ER are still regarded as gender-neutral actors although following a standard male norm. In contrast, organisational and management studies have engaged more fully with notions of men's power and masculinities (Connell, 1995).

Preference for defending the interests of men is a more overt form of resistance, and may reflect the enduring presence of patriarchal forces and values (Walby, 1990), even if the preference is sometimes defended under the flag of class interests. At a practical level, an apparent consensus to pursue gender equality interests may in the end prove to be conditional on it being also in the interests of the core group, that is men. These forms of resistance may of course be interrelated and take both conscious and unconscious forms.

Revitalisation may also be hampered by risks to both class and gender interests that may arise from applying a gender lens. The risks to class interests may take three main forms. First, including gender alongside class (and even disregarding consideration of other bases for discrimination) poses risks of fragmentation of worker interests. These are exacerbated where interests defined by gender and class combined constitute, as an intersectional perspective implies (Crenshaw, 1991), non-comparable experiences and issues. A second type of risk occurs when those developing a gender critique are not in a position of power to influence or shape any subsequent reform programme. Such gender critiques may be co-opted or utilised by more powerful interests for ends that differ from and even oppose the interests of those initiating the call for reform. This has been articulated by Nancy Fraser (2009: 108) by raising concerns that the feminist critique of the male breadwinner model might feed the "new spirit of capitalism' and thereby enter into a 'dangerous liaison with neoliberalism'. This risk increases where the same term covers many different meanings. A core example is flexibility: for some, flexible labour markets means responding to employee needs and preferences, but for others it means the needs of employers becoming dominant. A third example of risks is that gender equality may increase class inequalities, particularly at a household level. These dilemmas have been recently articulated by Milkman (2016) in the context of the United States, where growing inequalities among women as well as among men are exacerbating household-based class inequalities.

Equally there are serious risks for the gender equality agenda. One is that apparent advances may reflect more the erosion of men's more advantaged position than the upgrading of women's position. In addition, policies that on average have positive effects for women may impact differently according to women's social class, ethnicity, age and other characteristics. Research may also focus not on gender but on biological sex-related differences, which may serve to reinforce stereotypes rather than recognising that gender relations are dynamic and subject to change (Rubery, 2011). Even making gender and associated inequalities more visible entails risks, whether or not the focus is on equal treatment or on 
accommodating difference. For example, adjustment in work arrangements to accommodate care responsibilities could reinforce gender differences and not result in either more equal sharing with men or more care services. Alternatively, where there is a focus on equal treatment, care responsibilities may remain a hidden impediment to women's chances. Furthermore, by making the 'doing of gender' more visible, the sexualisation of work and the workplace is exposed and potentially 'normalised'. This raises the risk that it may be difficult to put the genie back in the bottle, making it less likely that the world of work could become a realm in which gender is not a significant factor in shaping experiences and behaviour.

\section{Embedding ER in social reproduction}

\section{Revitalisation}

Integrating the central feminist demand to give social reproduction equal weight with production constitutes a seismic shift in ER perspectives, not an adjustment on the margin. The feminist perspective considers the organisation of production to be dependent on that of social reproduction (Fraser, 2009); the male breadwinner employment model is supported by the gender division of household work that enables the male breadwinner and his employer to engage in production free from the constraints of care responsibilities.

This proposition extends the scope of the ER discipline in three main ways. First, it widens the lens beyond the currently employed or unemployed as the organisation of social reproduction influences who is included in the labour supply. So-called full employment may be achieved through processes of exclusion, operating through both social norms and an absence of care provision. Second, it provides a direct focus on the integration or separation of work and care. Third, it fills a hole in the comparative international research on ER that so far has emphasised interactions between ER and political, education and training and production systems regimes with a much more limited focus on gender, family and welfare systems (Bosch et al., 2009). Esping-Anderson's (1990) seminal contribution linked the welfare state form to labour market characteristics, but neglected both the institution of the family and also those - mainly women - who remained outside or only marginally integrated into wage labour. Feminist scholars quickly plugged this gaping hole by expanding the state - market framework to state - market family (Orloff, 1993), and characterising welfare states by support for the male breadwinner model (Lewis, 1992) or for their treatment of women as primarily workers, wives or mothers (Sainsbury, 1996). Care was found to be shaping both labour supply and the organisation of employment, particularly the growth of parttime jobs. This illustrates the need not only to consider social reproduction alongside production, but also to track their interactions if ER scholars are to make progress in understanding one of the core ER challenges, namely the growth of precarious work. 


\section{Resistance}

ER after the Second World War was dominated by a static production-focused systems approach (Dunlop, 1958). Trade union concerns at the end of the war period that women could act as a reserve army (Milkman, 2016) were quickly forgotten once the women mobilised for the war effort had returned to the home. Despite a wealth of comparative welfare and family system research, this neglect of women's role in ER continues, reflecting various forms of resistance to adopting or utilising a gender lens. Gender blindness is evident in, for example, influential theories of dualisation of ER in France and Germany. Despite recognition of women's role in the growth of non-standard employment, the characterisation of this dualisation as a new form of equilibrium ignores women's changing aspirations that might act to disrupt this new dualistic equilibrium (Palier and Thelen, 2010).

Gender marginalisation is also common among both ER practitioners and ER scholars. Equality bargaining has been found to be often confined by union negotiators to adjusting working time for women only (e.g. collective bargaining on gender equality focuses mainly on work - life balance issues; European Trade Union Confederation (ETUC), 2014; Gregory and Milner, 2009). Flexibility is considered either to be related to neoliberalism (Jepsen and Serrano Pascual, 2006) or to be a work - life balance issue (see Rubery et al., 2016, for a review of alternative meanings), and the complex interconnections between them are rarely addressed (see Fleetwood, 2007, for an exception). Moreover, the need for general reform of working time has not emerged on the agenda in response to gender equality; even the French 35-hour week focused on reducing unemployment without much concern for the gender consequences of the more flexible working schedules employers demanded in return for the shorter hours (Fagnani and Letablier, 2004).

Gender preference, that is for the protection of male interests, has also re-emerged during the great recession, sometimes labelled a man-cession. The risks for women have been underestimated and policies such as the German short-time working policy hailed as a new economic miracle, although three-quarters of the beneficiaries were men (Eydoux, 2014). By and large the gendered impact of austerity measures have been left unanalysed (see Karamessini and Rubery, 2014): research on the impact of austerity on the feminised public sector still maintains a gender-neutral perspective (see Rubery, 2013, for a review).

\section{Risks}

The risks foreseen by Fraser that the feminist critique of the male-breadwinner labour market could feed the new neoliberal spirit of capitalism clearly came to fruition in the European Union's employment strategy. Here, policies proposed by the gender equality unit to promote more gender-equal care work were co-opted by the wider European Commission to promote neoliberal employer-friendly 
flexible labour markets (Stratigaki, 2004). Fleetwood (2007) points to employers' use of work-life-balance policies for mothers as a smokescreen for the wider trend towards non-family-friendly working hours for most workers.

With hindsight, feminists could have been more alert to risks in a context of strong international drivers for deregulation. Likewise, ER scholars and practitioners can be criticised for doing too little to accommodate gender equality demands within more inclusive labour markets. In practice, trade unions have vacillated between complete opposition to flexible working or acquiescing in its concentration in marginal jobs located outside of collective regulation. Only a few countries, for example Sweden, integrated flexible working within regular work, by providing rights to reduce working hours up until a child is eight and a right to return to full-time hours.

A second type of risk is that policies presumed positive for gender equality may have very variable outcomes by class. For example, Mandel and colleagues (Mandel and Semyonov, 2006; Mandel and Shalev, 2009) argue that strong welfare states and high shares of public sector employment enable lower-educated women to work, but create stronger glass ceilings for higher-educated women in the private sector. Pettit and Hook (2009) identify differential take-up of family support policies by social class: the lower paid take up part-time work options that close down career options rather than the higher-cost formal childcare opted for by the higherpaid women. Likewise, Özbilgin et al. (2011) argue that work-life balance research has focused on women who are "white, middle class, engaged in white collar work, involved in a heterosexual relationship and the parent of young children' (p. 191). The outcome is silences around men, non-heterosexual couples and ethnic minorities in research that 'fails to recognise how factors such as educational and/or economic privilege or disadvantage, unequal access to power and resources collude in shaping the experiences of the work-life interface' (p. 189).

Another example of very mixed effects by class relates to women's status as permanent members of the wage labour force. This may be an empowering development for higher-educated women, but for lone parents and those at risk of being reliant on unemployment benefits, the requirement to seek work may constitute a new kind of oppression if they are pressured into working despite poor job prospects and high care demands (Cain, 2016). These policies may be presented as gender neutral or even as promoting gender equality, but in the UK they have coincided with cutbacks in childcare support targeted at low-income households (e.g. Surestart centres) and increasing sanctions on those who do not actively seek work.

A third type of risk is the reinforcement of women's roles as wives or mothers (Acker, 2006). Women still constitute the majority of those providing care through taking parental leave or seeking reduced working hours. In this context, long parental leaves and policies to allow reduced hours may be less likely to promote gender equality than policies aimed at limiting hours within full-time jobs which might enable women to work full-time and men to share in childcare (Fagan and Norman, 2016). As Acker noted (2006: 457), family-friendly policies or part-time 
work primarily involving women '... may reinforce, not undermine, the male model of organizing by defining those who conform to it as serious, committed workers and those who do not as rather peripheral and probably unworthy of promotions and pay increases ...'?

Thus, without more systemic change the chances of greater gender equality at work are limited.

\section{Intersectionality and representation}

\section{Revitalisation}

A gender lens influenced by an 'intersectional sensitivity' (McBride et al., 2015) has been taken up by feminist ER scholars to emphasise the need for union agendas to recognise the multiple disadvantage faced by particular groups and how the issues women face are shaped, for example by ethnicity and sexual orientation (Healy et al., 2004; Colgan and McKearney, 2012). This frame of intersectionality, originating in the Black feminist critique of White feminism (Crenshaw, 1991), has become part of the agenda of revitalising union structures, union organising and union priorities. For example, this has involved reflecting on whether women's separate structures can recognise the presence of multiple identities beyond simply gender and class (Holgate et al., 2006).

Significantly, recognition of the complex nature of identities at what McCall (2005) identifies as 'the neglected points of intersection' (p. 1773) has created a space to engage with broader notions of activism that encompass wider community organising and the distinctive motivations that shape the activism of marginalised groups. For example, Kirton's (2010) research on ethnic women's union participation shows how community activism and religious obligation shaped their union activism. Tapia et al.'s (2017) study of the organisation of low-wage workers in the US restaurant industry also showed the success of alternative forms of community organising on the basis of their work and non-work identities as racial minorities, women and immigrant workers. Briskin (2008) also uses a frame of intersectionality to explore how coalition building within more traditional union structures can be successful, and how cross-constituency organising between and across equityseeking groups can address multiple and competing identities to form part of a combined union revitalisation and union equality project (p. 242).

\section{Resistance}

Resistance to the incorporation of gender interests into ER has waned as women's share of trade union membership has risen. Most unions in the UK and elsewhere have introduced mechanisms for combining gender and class interests in their organisational structures and decision-making practices. However, gender is also still treated as a women's issue and not an issue for men, and masculine exclusionary practices within union structures still prevail although weaker than before 
(Ledwith, 2012b). The superficiality of unions' commitment to women's representation is indicated, for example, by the absence of discussion of the consequences of union mergers for the representation of women's interests (McBride and Waddington, 2009), despite Colgan and Ledwith's (1996) findings that opportunities for women and other minority groups are reduced because of the post-merger streamlining of organisational hierarchies.

Resistance to a non-hierarchical intersectional approach is also indicated by research that shows White middle-class women tending to dominate women's groups and Black men dominating Black groups (Healy et al., 2004). This reveals 'the overlapping realities of privilege and discrimination, so a white woman is both privileged on the basis of her race, and oppressed on the basis of her gender' (Briskin, 2014: 228). This tendency for the traditionally more powerful groups to prevail even within structures designed to support the disadvantaged in part reflects the problem of how to 'do intersectionality' (Healy et al., 2010) that may lead to the potential risks of both inaction and fragmentation, as we discuss next.

\section{Risks}

The general problem of how to 'do intersectionality' (Healy et al., 2010) is associated with the almost inevitable tendency to prioritise some inequalities over others. Furthermore, for intersectionality to be politically useful, the analysis needs to reveal not only specificities, but also regularities in these intersections and how these shape inequalities (Bradley, 2007: 192). Another problem is that trade unions have to balance their roles as promoters of 'swords of justice' with maintaining their power bases within the production system that provide the bread and butter of union funding and activism. At times, this may mean prioritising their current members' interests to the detriment of groups that are currently underrepresented among their members. Hyman (1999, summarised in Heery, 2003) has, however, made the interesting proposition that although the emergence of multiple identities may be undermining the current particular model of trade unionism based on traditional male manual workers' solidarities, a new model of trade unionism may yet emerge 'based on 'organic solidarity' and the reconciliation of new and more diverse interests grounded in gender, ethnicity, and other social identities' (Heery, 2003: 279).

Yet paradoxically, it has been observed that the concept of intersectionality and the agenda of the reconciliation of diverse interests and identities may, inadvertently, lead to the marginalisation of gender in ER debates and practice. Just as feminist arguments may be co-opted by a neo-liberal agenda, ER feminist scholars recognise the risks of intersectionality arguments being co-opted into ER to re-establish a gender-neutral approach that jeopardises some of the gender equality gains that have been made. Briskin (2014) observes that the language of intersectionality has led to the suggestion that 'gender inequality' does not capture the complexity of the inequalities that are experienced and lived by different groups of women. The risk is that this may detract from recognition of the continuing 
systemic inequalities that women face as a group. Kirton's (2014) study of the move towards more integrated equality structures and strategies found that while these help in enabling responses to other marginalised groups and their multiple and intersecting identities, the price may be that 'action on women is at a standstill' and that 'there are fewer resources available to tackle the complexities inherent in the gender democracy project' (p. 502).

The risk of gender marginalisation can be seen in one study of union efforts to organise migrant workers working mainly as cleaners (Alberti et al., 2013). Initially, the union attempted to take a 'particularistic approach' that recognised migrant workers have specific needs and face different forms of oppression from non-migrant workers. The researchers found, however, that the union quickly slipped back into a class-based approach, treating the migrant workers as generic workers. While this example demonstrates resistance within unions to an intersectional lens, significantly for our analysis, it also exposes the risk of gender marginalisation when ER scholars and practitioners focus on particular identities. The study does not discuss the gendered nature of this work, whether the migrants were male or female, or how gender may have shaped responses to the particularistic or more universal class-based approach. The risk is that gender may either be presented as ' having already been done' (for Alberti et al., gender is a 'traditional equality issue') or it is integrated into an all-encompassing approach in which gender is meshed with other inequalities, thereby inadvertently leading to a gender-blind analysis.

The umbrella approach to inequalities designed to capture an array of intersecting inequalities is also converging with what Briskin (2014) identifies as a language of equality that has been 're-invested with class content in the context of the growing gap between the rich and poor' (p. 124). She argues that the exacerbation of economic hardship by austerity is justifying a retreat from equality initiatives to a more generic talk of 'fairness'. However, without a robust analysis of what changes are needed to bring about gender equality, an argument for fairness may simply reproduce the old gender order. This inadvertent silencing of gender in ER is a risk both to the revitalisation agenda of ER and to those seeking to continue the process of gendering ER. As Briskin argues, 'both an intersectional sensitivity to capture lived experience of discrimination, and a continued emphasis on women are important' (p. 123).

\section{Using equal value to challenge market values}

\section{Revitalisation}

Rights to equal pay for work of equal value provide a major opportunity to challenge the value of wages set by the so-called market. This supports the core rationale for the study of ER, namely the proposition that the employment relationship is a social relationship, shaped by power relations. Consequently, institutionalised systems and regulations are needed to constrain the impact of power in the setting 
of employment conditions, including wages. This view on employment has been overshadowed in recent years by more of a market orientation, associated with individualised pay setting as collective regulation of wages has declined. The opportunity to question the value of wages set by the market should in principle provide ER with renewed tools and arguments to question the efficiency and equity of so-called market-determined pay. Embracing the gender critique that the market reinforces gender disadvantage could thus strengthen the defence of collectivelydetermined pay compared to a supposedly neutral market. The neutrality of the market was questioned by Beatrice and Sidney Webb (Farnham, 2008); parasitic industrialists exploit workers, such as women and young people who may sell their labour power for below subsistence needs, facilitated by intra-family subsidies. That is, the market was stratified and structured by the male breadwinner system of social reproduction. This argument has been deployed within UK law to limit the use of market factors as a defence in explaining gender pay gaps for work that is similar, rated equivalent or deemed of equal value. Even though market factors may sometimes be accepted as a defence, this may not be accepted if the market itself is considered discriminatory; for example, a case in the UK was rejected when the market value of catering work was deemed to be low, in part because catering workers are, for the most part, women. ${ }^{1}$

Yet despite these promising consequences of the equal pay for work of equal value principle, both trade union action and ER scholarship in this area has been limited. We explore the reasons for this in the following.

\section{Resistance}

The right to equal pay for work of equal value could in principle have had a huge impact as it opened doors to question both market and customary differentials. Much of the blame (or credit, depending on viewpoint) for keeping the lid on the equal pay revolution applies to the legislators who in most countries, including in the EU, mainly adopted a narrow concept of equal value, confined to a single employer and dependent on male/female comparators within that same employing organisation. There are only a few jurisdictions - for example Ontario (see Rubery and Koukiadaki, 2016, for a review) - where comparisons without a direct male comparator are possible. This limited the legislative scope, particularly in the private sector, as each case applied only to an individual employer. However, trade unions have also been reluctant to press for a radical revaluation of jobs. This may be because by accepting the gender critique of market value they must also consider the parallel critique that gender pay inequality has been embedded in collectively bargained wage structures (Schäfer and Gottschall, 2015). Indeed some of the most sustained efforts to introduce equal pay for work of equal value, at least in the public sector, have been made by trade unions in countries such as the UK and the US, where collective bargaining is on the retreat. Reluctance to embrace the gender critique of collectively determined pay differentials may be greater where there is potentially more to lose, for example in Germany (Schäfer and Gottschall, 2015). 
However, there are exceptions, and trade unions in the Nordic countries have taken action on gender pay issues, even in the context of high collective bargaining coverage.

Where action is taken, examples of clear gender preference may still emerge. In the case of UK local authorities, the trade unions at national level negotiated a single-status pay spine using gender-sensitive evaluations, but when implemented at local level the trade unions proved to be more concerned about impacts on male employees than in securing the full back pay to which the undervalued women were entitled (Deakin et al., 2015). In a recent review in Finland of gender pay gaps in local authorities, the trade unions resisted moving to a single pay spine, such that most male-dominated jobs were not compared directly to female-dominated jobs (Koskinen Sandberg, 2016). In some cases trade unions failed in their efforts, perhaps indicating weak commitment. In Germany, the public sector union Ver.di failed to persuade employers to reevaluate jobs on an equal value basis, and even accepted a new lower entry pay rate to make the public sector more competitive with private subcontractors, thereby embedding the market valuation of female-dominated jobs (Bosch et al., 2012).

\section{Risks}

Resistance by trade unions and the ER community to using equal value legislation to challenge current constructions of value may in part reflect caution. Challenging existing collectively regulated differentials questions not only past trade union actions, but also the trade unions' traditional defence of custom and practice. Furthermore, the intervention favoured for reassessing value, namely job evaluation, is problematic. Not only is it difficult to ensure women's skills and attributes are visible and valued, but it also risks passing power to managers as the custodians of an apparently gender-neutral system of job grading (Figart et al., 2002). This misplaced belief in a technical solution to gender equality is vividly described in Acker's (1989) description of the efforts to implement comparable worth in Oregon state, an exercise supported by trade unions as well as feminists. The collaboration broke down as the management strategy to use this re-evaluation exercise as a way to marginalise trade unions' role in wage setting and reassert the managerial right to define jobs and pay became evident. Even when upgrading of women's jobs was agreed on, for example in the case of social care jobs in UK local government, this was not the end of the story as this upgrading was followed by widespread outsourcing of social care to the private sector where only minimum wages are paid (Grimshaw et al., 2015; Hebson et al., 2015).

Thus, opening up existing wage structures to re-examination can be a risky enterprise viewed from a class perspective. However, research has also revealed the risks from pay setting outside the auspices of trade unions (Gannon et al., 2007) as rent sharing and individualised performance pay under management decisions 
has generated new forms of gender pay inequalities, providing further arguments against the marketisation of pay.

Another risk from equal pay demands is widening class inequalities at a household level (Milkman, 2016). Without changes to the overall pay range, inequalities at the household level could widen, due to a trend towards 'assortative mating' such that both partners may be high or low earners. To serve both gender and class interests, it is necessary not only for pay for workers in equivalent jobs to receive comparable pay, regardless of gender, but also for the range of pay to narrow. This could be achieved both by raising the minimum wage floor and by compressing pay at the top end, particularly in highly unequal societies. However, by raising concerns that gender equality might increase class inequalities, there is a risk of a backlash against women who have medium or high earnings. For example, a right wing think tank in the UK appealed to risks of class inequalities to argue that improving maternity leave pay for lower-paid women should be funded by reducing that for higher-paid women. ${ }^{2}$ The outcome of such policies would be in practice to place further barriers on women acting as the main breadwinner in a household.

\section{Doing gender and embodying work}

\section{Revitalisation}

The final area for extending and deepening ER scholarship relates to new approaches to understanding gender in the workplace. Approaches developed in organisational studies, sociology and management studies conceptualise gender as an on going process and an accomplishment that individuals 'do', not a static category that someone 'has' (Calás et al., 2014; West and Zimmerman, 1987). Within this broad area there are different approaches to what 'doing gender' entails: West and Zimmerman's (1987) account is more characteristic of an ethnomethodological focus on how gender is produced through everyday social interactions between men and women in ways that maintain and reproduce the gender order; this differs from Butler's (2004) post-structuralist approach where the doing of gender is a result of 'discursive effects', that is where individuals create themselves as gendered subjects through gendered discourses (e.g. signs, language, rhetoric) that shape feelings, attitudes, behaviour and the sense of self (see Kelan, 2010, for an overview). Both approaches, however, have led to highly influential research agendas on embodiment and sexuality, all with potential for revitalising ER, especially under the current heightened awareness of sexual harassment in the workplace in high-profile arenas such as the media and film industry.

Calás et al. (2014) argue that embodiment is one of the theoretical concerns that arise from a focus on 'doing gender' as it recognises the ways 'the materialization of the human body as gendered plays an important part in the production of sex/gender inequalities in society and organizations' (p. 31). In particular, the ways sexuality and embodiment have come together in discussions of 
aesthetic labour and how bodies and heterosexuality are commodified in the labour process can provide a new expanded agenda for ER to extend beyond its traditionally material focus. Research on low-paid retail work, hospitality and bartending have all shown how in these low-paid jobs, gendered, classed and ethnic bodies are used to embody and sell the brand, creating a culture where sexual harassment is acceptable and part of the job (Warhurst and Nickson, 2009). This wider sexualisation can be seen in professional and corporate contexts, confirming Hakim's (2010) view of the market value of 'erotic capital'. For example, in Sommerlad's (2016) study of the legal profession, the sexualisation of women was common in the more lucrative deals where 'client care' meant they were expected to accept harassment. Likewise, Caven and Lawley's (2013) study of recruitment agencies revealed the pressure women felt to perform 'compulsory heterosexuality' and draw on their aesthetics and sexuality to secure deals with their clients. McDowell's (2010) study of corporate banking found excessive masculinity related to over-confidence and risk taking that has been linked to the financial crisis. While corporate banking is possibly an extreme example, these 'hyper-masculine' work cultures are symptomatic of a wider sexualisation of corporate cultures that are increasingly common and are also predicated on compulsory heterosexuality. Significantly, focusing on how gender is done through 'compulsory heterosexuality' reveals that some men and masculinities are more powerful or privileged than others. Simpson and Lewis (2007) argue that heterosexual masculine practices are valorised compared to homosexual masculinities, and emphasise that gender does not solely harm women. Pringle's (2008) study of lesbian women managers also shows the challenges they face when assessed through a heterosexual gaze.

A gender lens that focuses on embodiment has also put occupations that require body work at the centre of employment issues and inequalities. Body work has been defined as 'focusing directly on the bodies of others; assessing, diagnosing, handling, and manipulating bodies, which thus become the object of the worker's labour' (Twigg et al., 2011: 171-188). Such work can encompass a wide range of health and social care jobs, sex work, aesthetic services such as beauty work, and protective and security services. Cohen and Wolkowitz (2018) argue that the low wages attached to this work are a reflection of employers' reproduction of the cultural associations between touch and femininity (p. 55) with respect to work traditionally performed outside of the market by women (either in the home or provided by the state). Furthermore, they point to evidence of racialisation of body work whereby particular ethnic femininities and masculinities may be more or less favoured in certain types of body work, reflected for example in preferences for certain migrant workers' 'feminized whiteness' or for the 'subservient masculinities' of ethnic minority men (p. 57).

This recognition of the ubiquitous nature of bodies and sexuality in influencing not only workplace relations but also client relations, extending to even the explicit marketing of products and services, provides a new potential perspective on the gendered and classed experiences of work and puts new issues on the potential 
bargaining table. Likewise, new debates on body work extend understanding of the gendering of work beyond emotional labour to a focus on the need to dissociate touch from femininity and domesticity and challenge the predatory associations of masculine touch (Cohen and Wolkowitz, 2018).

\section{Resistance}

This ambitious agenda for ER research to encompass 'doing gender' has not yet been taken up by many scholars who associate themselves primarily with ER. Briskin (2006) notes that men remain 'ungendered' in ER and ER seems to be particularly tied to the 'gender neutral, abstract worker' (Acker, 2012: 218) who has been challenged in other disciplines. For example, the burgeoning literature on fathers at work and the ways fathers feel 'invisible at work in their paternal role' (Burnett et al., 2013: 632) is absent from ER debates. Resistance in trade unions to the gendering of men is also evident. For example, Ravenswood and Markey (2011) found that trade unions in New Zealand did not see family-friendly policies to be relevant in male-dominated workplaces, and in France, Brochard and Letablier (2017) reveal how unions failed to grasp the opportunity to mobilise around workfamily balance issues, despite a government call for action at the company level because unions continue to silo this into a women's issue.

There have also been limited actions to foreground new dimensions of skill, such as emotional labour, in bargaining over pay and conditions (Arthurs, 2004) and demands for such valorisation have led some ER scholars (Payne, 2009) to question the conceptualisation of emotional labour as a skill. While Payne queries the degree of complexity in emotional labour tasks, the core of his argument is that the work is not skilled because there is no social closure and no creation of a shortage of labour for this type of work to provide market-based support for organising strategies to raise its wage and status. Yet it is precisely this approach to skill, based on the market power of the occupational group, that has been challenged by feminists as it has resulted in the historical invisibility of the skills involved in tasks traditionally performed by women. There is also failure within ER to engage with the discriminatory ways employers combine their undervaluation of women's work with demands for specific aesthetic labour. Here there is a danger of reinforcing gender, class and racialised hierarchies in service work leading to feminists to argue for a strategy to 'debunk aesthetic labour, not to compensate it' (Williams and Connell, 2010: 372).

Issues of dress codes and links to sexualisation and gender differentiation are beginning to be addressed (Nath et al., 2016), though UK legal judgments still allow sex differentiation in dress codes provided they are equally strict, taken in the round. There are some examples of trade union action to protect sex workers: for example, in Canada there is cross-constituency organising across gender and lesbian, gay, bisexual or transgender (LGBT) groups to press for the decriminalisation of sex work and to promote unionisation and healthy and safe working conditions for sex workers (Briskin, 2008: 235). There is also more action on sexual 
harassment in the workplace, although this may be dressed in the more gender neutral language of bullying (Hunt et al., 2010), and also more recognition of third party client involvement. However, sexual harassment is still largely regarded as a breach of workplace good practice and implicit requirements for sexualised performance in particular jobs have not been a focus of either research or practitioner action.

\section{Risks}

In making the doing of gender visible and embodied there is the major risk of emphasising differences between women and men. Feminist arguments can be subverted for very different ends, and attention to the use of erotic capital or men's excessive masculinity could even legitimise arguments around gender difference that have been used to justify inequalities and maintain gender segregation. McDowell (2010) recognises this risk in her discussion of testosterone capitalism cited earlier, and reflects upon her scepticism and reluctance, as a feminist, to attribute social behaviour to biological mechanisms (p. 655). However, she also reflects that she cannot completely dismiss links between excessive masculinity and testosterone which, among other social explanations, 'give a further type of support' for men's 'irrational exuberance' in the financial crisis' (p. 656). Furthermore, making the sexualisation of the workplace and client relations more visible may even normalise such expectations. Likewise, the revaluing of touch advocated by Cohen and Wolkowtiz (2018) could serve to valorise women and men's differences rather than challenge them.

Yet despite these risks, the new emphasis on embodiment, emotions and sexuality must be central to developing a fuller understanding of the employment relationship at the core of the ER discipline. It provides, for example, a new perspective on the boundary roles that women undertake in client-driven cultures and on the service and body work that underpins much of the feminisation of the service sector. It can also offer new explanations to 'gendered puzzles'. For example, the sexualisation of work can provide an expanded frame for explaining why the gender pay gap for the young is relatively small but widens significantly for older age ranges by going beyond the traditional motherhood 'penalty' explanation to include decreasing sexual attraction with age.

\section{Conclusions}

ER is fundamentally concerned with wage work and class relations, but wage work is not done exclusively by men and class relations intersect with multiple identities. A single focus on class is thus neither appropriate nor likely to rejuvenate ER as either a social science discipline or a practice. A gender lens provides an important opportunity to embed the discipline in a more holistic understanding of ER. This would fill in the missing parts of the jigsaw through highlighting social reproduction alongside production, extend the scope of ER by recognising intersectional 
experiences and interests, strengthen the challenge to the new marketised logic of ER through the gender critique of market-based pay, and deepen understanding of work experiences by embracing gender as a process that is created and recreated within the workplace. However, the response to these opportunities to expand research horizons and demonstrate ER's continuing relevance to a wider constituency has so far been very modest, except for a small coterie of mainly female ER-based researchers. The scale of the challenge to the 'taken for granted' (Pocock, 1997) is either not understood or actively resisted, and gender issues continue to be treated as women's issues to be placed in silos or even displaced by newer concerns with identities by race, ethnicity, age and disability.

One explanation of resistance, that goes beyond the obvious one of continuing male dominance of ER, is that challenging accepted ways of thinking and doing involves risks. Nevertheless, mainstream ER scholars might still be expected to engage with these risks and suggest paths forward. With some notable exceptions (e.g. Hyman, 1999), it is often feminists who recognise and analyse the problems (Acker, 1989, 2006; Fraser, 2009; Milkman, 2016). For each of the possible areas of renewal and challenge, three forms of risk have been identified. First, critiques of ER could provide opportunities for employers to increase their power and control or for neoliberal policymakers to legitimise attacks on employment regulation. Second, by making gender more visible, gender differences may be used to legitimise or promote gender inequalities. Third, when prioritising and representing worker interests, many pitfalls may be encountered in charting a path between excessive fragmentation of worker interests and reproducing hierarchy - by class, gender or race.

We would argue, however, that despite these dangers it is much riskier for ER as a discipline and a practice not to engage with these challenges. Many of the core challenges for ER, such as renewing the organisational base, addressing the growth of precarious work and challenging the marketisation of the employment relationship, are all bound up with issues of gender and gender inequality. The costs of not engaging are thus not only to pass over opportunities for renewal, but also to fail to respond to critiques of ER's traditional narrow focus which may yet result in it withering on the vine.

\section{Declaration of conflicting interests}

The author(s) declared no potential conflicts of interest with respect to the research, authorship and/or publication of this article.

\section{Funding}

The author(s) received no financial support for the research, authorship and/or publication of this article.

\section{Notes}

1. www.thompsons-scotland.co.uk/equal-pay-genuine-material-factor-defences

2. www.theguardian.com/money/2017/jul/15/maternity-pay-tories-plan-take-from-rich-tohelp-poor 


\section{ORCID iD}

Jill Rubery (D) http://orcid.org/0000-0001-9405-0073

\section{References}

Acker J (1989) Doing Comparable Worth. Philadelphia, PA: Temple University Press.

Acker J (2006) Inequality regimes: Gender, class and race in organisations. Gender and Society 20(4): 441-464.

Acker J (2012) Gendered organizations and intersectionality: Problems and possibilities. Equality, Diversity and Inclusion: An International Journal 31: 214-224.

Ackers P and Wilkinson A (eds) (2003) Understanding Work and Employment. Oxford: Oxford University Press.

Alberti G, Holgate J and Tapia M (2013) Organising migrants as workers or as migrant workers? Intersectionality, trade unions and precarious work. International Journal of Human Resource Management 24(22): 4132-4148.

Arthurs A (2004) Emotional labour, equal value, and job evaluation. Working Paper, University of Bath School of Management, Bath.

Berg P and Piszczek M (2014) The limits of equality bargaining in the USA. Journal of Industrial Relations 56(2): 170-189.

Bosch G, Lehndorff S and Rubery J (eds) (2009) European Employment Models in Flux. Basingstoke: Palgrave, Macmillan.

Bosch G, Mesaros L, Schilling G and Weinkopf C (2012) The public sector pay system and public procurement in Germany. European Commission Project VS/2011/0141. Available at: www.research.mbs.ac.uk/ewerc/Portals/0/docs/Germany-national\%20report.pdf

Bradley H (2007) Gender. London: Polity Press.

Briskin L. (2006) Victimisation and agency: the social construction of union women's leadership. Industrial Relations Journal 37(4): 359-378.

Briskin L (2008) Cross-constituency organizing in Canadian unions. British Journal of Industrial Relations 46(2): 221-247.

Briskin L (2014) Austerity, union policy and gender equality bargaining. Transfer: European Review of Labour and Research 20: 115-133.

Broadbridge A and Simpson R (2011) 25 years on: Reflecting on the past and looking to the future in gender and management research. British Journal of Management 22: 470-483.

Brochard D and Letablier M (2017) Trade union involvement in work-family life balance: Lessons from France. Work, Employment and Society 3(4): 657-674.

Burnett S, Gatrell C, Coope C and Sparrow P (2013) Fathers at work: A ghost in the organizational machine. Gender, Work \& Organization 20(6): 632-646.

Butler J (2004) Undoing Gender. London: Routledge.

Cain R (2016) Responsibilising recovery: Lone and low-paid parents, Universal Credit and the gendered contradictions of UK welfare reform. British Politics 11(4): 488-507.

Calás M, Smircich L and Holvino E (2014) Theorizing gender-and-organization: Changing times ... changing theories? In: Kumra S, Simpson R and Burke RJ (eds) The Oxford Handbook of Gender in Organizations. Oxford: Oxford University Press, pp. 17-52.

Caven V and Lawley S (2013) Performance, gender and sexualised work: Beyond management control, beyond legislation? A case study of work in a recruitment company. Equality, Diversity and Inclusion: An International Journal 32(5): 475-490.

Cockburn C (1985) Machinery of Dominance. London: Macmillan. 
Cohen R and Wolkowitz C (2018) The feminization of body work. Gender, Work \& Organization 25(1): 42-62.

Colgan F (2012) Visibility and voice in organisations: Lesbian, gay, bisexual and transgendered employee networks. Equality, Diversity and Inclusion: An International Journal 31(4): 359-378.

Colgan F and Ledwith S (1996) Sisters organising - women and their trade unions. In: Ledwith S and Colgan F (eds) Women in Organisations. Basingstoke: Macmillan, pp.152-185.

Colgan F and McKearney A (2012) Visibility and voice in organisations: Lesbian, gay, bisexual and transgendered employee networks. Equality, Diversity and Inclusion: An International Journal 31(4): 359-378.

Colling T and Terry M (eds) (2010) Industrial Relations: Theory and Practice. Chichester: Wiley.

Connell RW (1995) Masculinities. Sydney: Allen and Unwin.

Crenshaw K (1991) Mapping the margins: Intersectionality, identity politics and violence against women of color. Stanford Law Review 1241-1299.

Crouch C. (1993) Industrial Relations and European State Traditions. Oxford: Clarendon Press.

Deakin S, Butlin S, McLaughlin C and Polanska A (2015) Are litigation and collective bargaining complements or substitutes for achieving gender equality? A study of the British Equal Pay Act. Cambridge Journal of Economics 39(2): 381-403.

Dibben P, Wood G and Klerck G (2011) Employment Relations: A Critical and International Approach. London: Kogan Page.

Dickens L (2000) Collective bargaining and the promotion of gender equality at work: Opportunities and challenges for trade unions. Transfer 6(2): 193-208.

Dunlop JT (1958) Industrial Relations Systems. New York: Henry Holt and Company.

Esping-Andersen G (1990) The Three Worlds of Welfare Capitalism. Princeton, New Jersey: Princeton University Press.

European Trade Union Confederation (ETUC) (2014) Bargaining Equality. Brussels: ETUC.

Eydoux A (2014) Women during recessions in France and Germany: The gender biases of public policies. Revue de l'OFCE Debates and Policies 132: 153-188. Available at: www.ofce.sciences-po.fr/pdf/revue/132/revue-132.pdf

Fagan C and Norman H (2016) Which fathers are involved in caring for pre-school age children in the UK? A longitudinal analysis of the influence of work hours in employment on shared childcare arrangements in couple households. In: Crespi I and Ruspini E (eds) Balancing Work and Family in a Changing Society: The Fathers' Perspective. Basingstoke: Palgrave Macmillan.

Fagnani F and Letablier M (2014) Work and family life balance: The impact of the 35-hour laws in France. Work, Employment and Society 18(3): 551-572.

Farnham D (2008) Beatrice and Sidney Webb and the intellectual origins of British industrial relations. Employee Relations 30(5): 534-552.

Figart D, Mutari E and Power M (2002) Living Wages, Equal Wages: Gender and Labour Market Policies in the United States. London: Routledge.

Fleetwood S (2007) Why work-life balance now? International Journal of Human Resource Management 18(3): 387-340.

Fraser N (2009) Feminism, capitalism and the cunning of history. New Left Review 56: $97-116$. 
Gannon B, Plasman R, Ryck F and Tojerow I (2007) Inter-industry wage differentials and the gender wage gap: Evidence from European countries. The Economic and Social Review 38(1): 135-155.

Gregory A and Milner S (2009) Trade unions and work-life balance: Changing times in France and the UK? British Journal of Industrial Relations 47(1): 122-146.

Grimshaw D and Rubery J (2007) Undervaluing women's work. Equal Opportunities Commission Manchester, Working Paper Series No. 53. Available at: www.equalityhumanrights.com/ uploaded_files/equalpay/undervaluing_womens_work.pdf

Grimshaw D, Rubery J and Ugarte S (2015) Does better quality contracting improve pay and HR practices? Evidence from for-profit and voluntary sector providers of adult care services in England. The Journal of Industrial Relations 57(4): 502-525.

Hakim C (2010) Erotic capital. European Sociological Review 26(5): 499-518.

Healy G, Bradley H and Mukherjee N (2004) Individualism and collectivism revisited - A study of black minority ethnic women. Industrial Relations Journal 35(5): 451-466.

Healy G, Kirton G and Noon M (2010) Inequalities, intersectionality and equality and diversity initiatives: the conundrums and challenges of researching equality, inequality and diversity. In: Healy G, Kirton G and Noon M (eds) Equality, Inequalities and Diversity, Basingstoke, Palgrave, pp.1-17.

Hebson G and Rubery J (2018) Employment relations and gender equality. In: Wilkinson A, Dundon T, Donaghey J, et al. (eds) The Routledge Companion to Employment Relations. London: Routledge.

Hebson G, Rubery J and Grimshaw D (2015) Rethinking job satisfaction in care work: Looking beyond the care debates. Work, Employment and Society 29(2): 314-330.

Heery E (2003) Trade unions and industrial relations. In: Ackers P and Wilkinson A (eds) Understanding Work and Employment. Oxford: Oxford University Press, pp. 278-304.

Heery E and Conley H (2007) Frame extension in a mature social movement: British trade unions and part-time work, 1967-2002. Journal of Industrial Relations 49(1): 5-29.

Holgate J, Hebson G and McBride A (2006) Why gender and "difference" matters: a critical appraisal of industrial relations research. Industrial Relations Journal 37(4): 310-328.

Hunt C, Davidson M, Fielden S and Hoel H (2010) Reviewing sexual harassment in the workplace - An intervention model. Personnel Review 39(5): 655-673.

Hyman R (1999) Imagined solidarities: Can trade unions resist globalization? In: Leisink P (ed.) Globalization and Labour Relations. Cheltenham: Edward Elgar, pp. 94-115.

Jepsen M and Serrano Pascual A (eds) (2006) Unwrapping the European Social Model. Bristol: Policy Press.

Karamessini M and Rubery J (2014) Women and Austerity: The Economic Crisis and the Future for Gender Equality. Abingdon: Routledge.

Kelan EK (2010) Gender logic and (un)doing gender at work. Gender, Work \& Organization 17(2): 174-194.

Kirton G (2010) Work-life-balance: attitudes and expectations of young black and minority ethnic graduates. In Healy G, Kirton G and Noon M (2010) (eds) Equality, Inequalities and Diversity, Basingstoke: Palgrave Macmillan.

Kirton G (2014) Progress towards gender democracy in UK unions 1987-2012. British Journal of Industrial Relations 53(3): 484-507.

Koskinen Sandberg P (2016) The Politics of Gender Pay Equity: Policy Mechanisms, Institutionalised Undervaluation, and Non-Decision Making. Helsinki: Hanken School of Economics. Available at: https://helda.helsinki.fi/bitstream/handle/10138/167165/ 305_978-952-232-322-4.pdf 
Lansbury R (2009) Work and industrial relations: Towards a new agenda. Relations Industrielles/Industrial Relations 64(2): 326-339.

Ledwith S (2012a) Outside, inside: Gender work in industrial relations. Equality, Diversity and Inclusion: An International Journal 31(4): 340-358.

Ledwith S (2012b) Gender politics in trade unions. The representation of women between exclusion and inclusion. Transfer 18(2): 185-199.

Lewis J (1992) Gender and the development of welfare regimes. Journal of European Social Policy 2(3): 159-173.

McBride A, Hebson G and Holgate J (2015) Intersectionality: Are we taking enough notice in the field of work and employment relations? Work, Employment and Society 29(2): 331-341.

McBride A and Waddington $\mathbf{J}$ (2009) The representation of women and the trade union merger process. In: Foley $\mathrm{J}$ and Baker $\mathrm{P}$ (eds) Unions, Equity and the Path to Renewal. Vancouver: UBC Press, pp. 192-218.

McCall L (2005) The complexity of intersectionality. Signs: Journal of Women in Culture and Society 30(3): 1771-1800.

McDowell L (2010) Capital culture revisited: Sex, testosterone and the city. International Journal of Urban and Regional Research 3(4): 652-658.

Mandel H and Semyonov S (2006) A welfare state paradox: State interventions and women's employment opportunities in 22 countries. American Journal of Sociology 111(6): 1910-1949.

Mandel H and Shalev M (2009) Gender, class and varieties of capitalism. Social Politics 16(2): 161-181.

Martinez Lucio M (ed.) (2014) International Human Resource Management: An Employment Relations Perspective. London: SAGE.

Milkman R (2016) On Gender, Labor and Inequality. Champaign, IL: University of Illinois Press.

Nath V, Bach S and Lockwood G (2016) Dress codes and appearance norms at work: Body supplements, body modifications and aesthetic labour. ACAS Research Paper 7/16. London: ACAS.

Orloff A (1993) Gender and the social rights of citizenship: The comparative analysis of gender relations and welfare states. American Sociological Review 58(3): 303-328.

Özbilgin MF, Beauregard TA, Tatli A and Bell MP (2011) Work-life, diversity and intersectionality: A critical review and research agenda. International Journal of Management Reviews 13(2): 177-198.

Palier B and Thelen K (2010) Institutionalizing dualism: Complementarities and change in France and Germany. Politics \& Society 38(1): 119-148.

Payne J (2009) Emotional labour and skill: A reappraisal. Gender, Work \& Organization 16(3): $348-367$.

Pettit B and Hook J (2009) Institutionalizing Inequality: Gender, Family, and Economic Inequality in Comparative Perspective. New York: Russell Sage.

Piore MJ (2011) Whither industrial relations: Does it have a future in post-industrial society? British Journal of Industrial Relations 49(4): 792-801.

Pocock B (1997) Gender and Australian industrial relations theory and research practice. Labour and Industry 8(1): 1-19.

Pringle JK (2008) Gender in management: Theorizing gender as heterogender. British Journal of Management 19(2): 110-119. 
Ravenswood K and Markey R (2011) The role of unions in achieving a family-friendly workplace. Journal of Industrial Relations 53(4): 486-503.

Rubery J (2011) Towards a gendering of the labour market regulation debate. Cambridge Journal of Economics 35(6): 1103-1126.

Rubery J (2013) Public sector adjustment and the threat to gender equality. In: VaughanWhitehead D. (ed) Public Sector Shock: The Impact of Policy Retrenchment in Europe: The Impact of Policy Retrenchment in Europe. Edward Elgar Publishing, Cheltenham, pp. 43-83.

Rubery J and Fagan C (1995) Comparative industrial relations research: Towards reversing the gender bias. British Journal of Industrial Relations 33(2): 209-236.

Rubery J and Koukiadaki A (2016) Closing the Gender Pay Gap: A Review of the Issues, Policy Mechanisms and International Evidence. Geneva: International Labour Organization.

Rubery J, Keizer A \& Grimshaw D (2016) Flexibility bites back: the multiple and hidden costs of flexible employment policies. Human Resource Management Journal 26 (3): 235-251.

Sainsbury D (1996) Gender Equality and Welfare States. Cambridge: Cambridge University Press.

Schäfer A and Gottschall K (2015) From wage regulation to wage gap: How wagesetting institutions and structures shape the gender wage gap across three industries in 24 European countries and Germany. Cambridge Journal of Economics 39(2): 467-496.

Simpson R and Lewis P (2007) Voice, Visibility and the Gendering of Organizations. Basingstoke: Palgrave Macmillan.

Sommerlad H (2016) "A pit to put women in": Professionalism, work intensification, sexualisation and work-life balance in the legal profession in England and Wales. International Journal of the Legal Profession 23(1): 61-82.

Stratigaki M (2004) The co-optation of gender concepts in EU policies: the case of "reconciliation of work and family". Social Politics 11(1): 30-56.

Tapia M, Lee T and Filipovitch M (2017) Supra-union and intersectional organizing: An examination of two prominent cases in the low wage US restaurant industry. Journal of Industrial Relations 59(4): 487-509.

Twigg J, Wolkowtiz C, Cohen R and Nettleton S (2011) Conceptualising body work in health and social care. Sociology of Health and Illness 33(2): 171-188.

Wajcman J (2000) Feminism facing industrial relations in Britain. British Journal of Industrial Relations 38(2): 183-201.

Walby S (1990) Theorising Patriarchy. Oxford: Blackwells.

Warhurst C and Nickson D (2009) "Who's got the look?" Emotional, aesthetic and sexualized labour in interactive services. Gender, Work \& Organization 16(3): 385-404.

West C and Zimmerman D (1987) Doing gender. In: Fenstermaker S and West C (eds) Doing Gender, Doing Difference. London: Routledge, pp. 3-24.

West C and Zimmerman D (1987) Doing gender. Gender and Society 1(2): 125-51.

Wilkinson A, Wood G and Deeg R (2014) The Oxford Handbook of Employment Relations. Oxford: Oxford University Press.

Williams C and Connell C (2010) "Looking good and sounding right": Aesthetic labor and social inequality in the retail industry. Work and Occupations 37(3): 349-377. 


\section{Biographical notes}

Jill Rubery is Professor of Comparative Employment Systems at Alliance Manchester Business School, University of Manchester, and the Director of the Work and Equalities Institute at Manchester. Her research focuses on the interdisciplinary comparative analysis of employment systems and gender equality. Recent publications include Women and Austerity: The Economic Crisis and the Future for Gender Equality (with M. Karamessini; Routledge, 2014, 'The 40-year pursuit of equal pay: a case of constantly moving goalposts', Cambridge Journal of Economics (with D. Grimshaw, 2015, and @'Austerity and the future for gender equality in Europe', Industrial and Labor Relations Review (2015).

Gail Hebson is Senior Lecturer in Employment Studies at the Alliance Manchester Business School. Her research interests include gender and class divisions in employment, theorizing intersectionality and the experience of work in low-paid occupations. Publications include 'Rethinking job satisfaction in care work: Looking beyond the care debates', Work, Employment and Society (with Jill Rubery and Damian Grimshaw, 2015) and 'Intersectionality: Are we taking enough notice in the field of work and employment relations?', Work, Employment and Society (with Anne McBride and Jane Holgate, 2015). 